\title{
PENGARUH KEPEMIMPINAN TRANSFORMASIONAL TERHADAP KINERJA KARYAWAN DENGAN EMPLOYEE ENGAGEMENT SEBAGAI VARIABEL PEMEDIASI STUDI DI BPRS YOGYAKARTA \\ Nevi Laila Khasanah
}

Dosen PAI STAI Bumi Silampari

nevilailakhasanah@yahoo.com

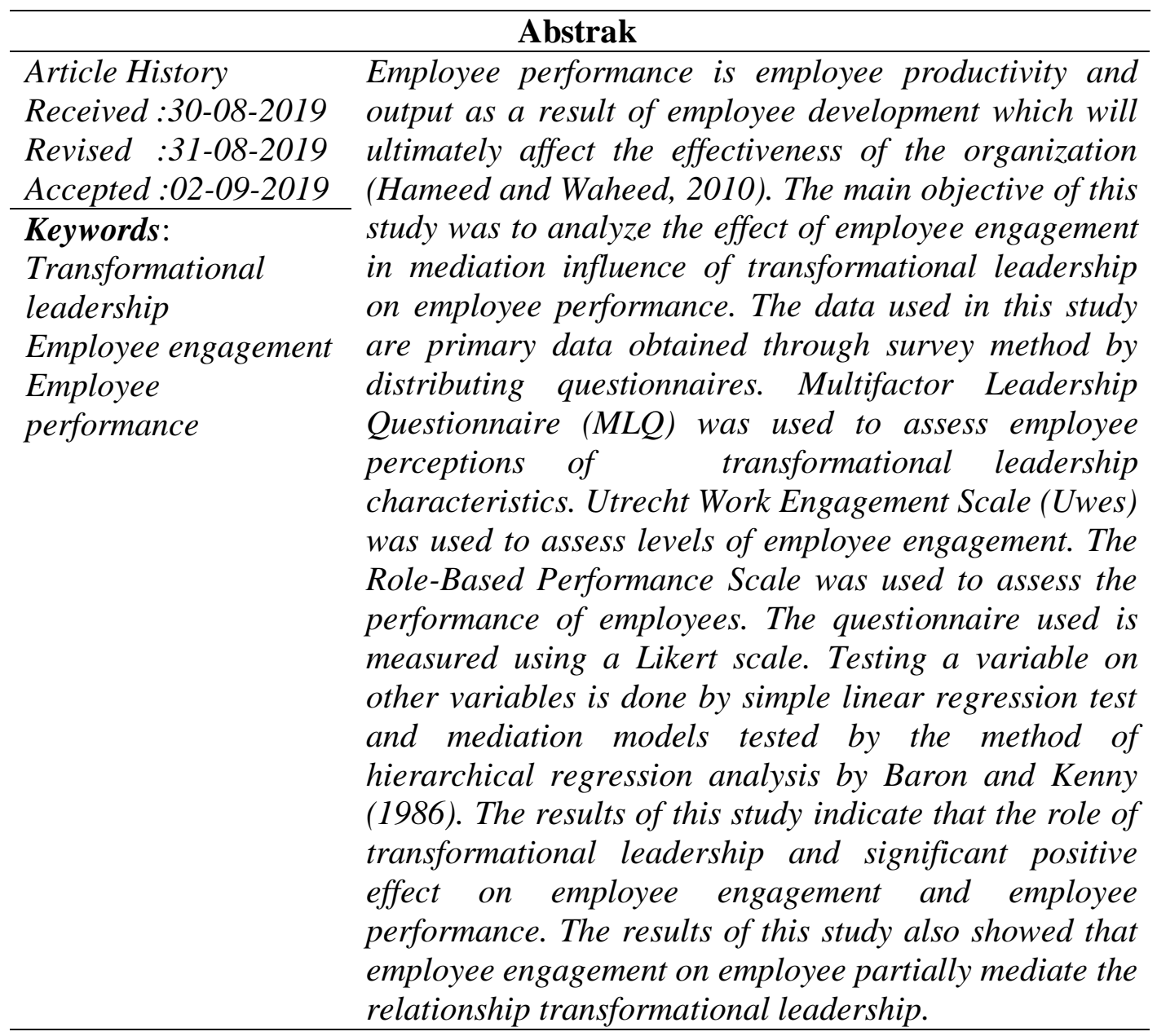

\section{Pendahuluan}

Kinerja karyawan adalah produktivitas dan output karyawan sebagai hasil dari pengembangan karyawan yang pada akhirnya akan mempengaruhi efektivitas organisasi (Hameed dan Waheed, 2010). Kinerja karyawan menunjukkan efektivitas karyawan dalam melakukan tindakan khusus dalam berkontribusi untuk mencapai tujuan organisasi sesuai dengan job description (Iqbal et al., 2015). Menurut Saetang et al. (2010), kinerja karyawan merupakan hasil dari perilaku karyawan yang merupakan faktor penting untuk evaluasi efektivitas kerja individu. Dari pandangan ini, dapat dikatakan bahwa keberhasilan atau kegagalan organisasi tergantung pada kinerja karyawan dalam organisasi tersebut.

Kinerja karyawan dapat dilihat dari berbagai aspek. Salah satu aspek kinerja karyawan adalah produktivitas. Berdasarkan penelitian Welbourne et al. (1998) aspek kinerja karyawan meliputi job, career, innovator, team dan organization. Beberapa penelitian juga telah memperkenalkan berbagai aspek kinerja karyawan 
antara lain kualitas, kuantitas, pengetahuan atau kreativitas individu terhadap karya yang dicapai yang sesuai dengan tanggung jawab selama periode yang telah ditentukan. (Wong dan Wong, 2007).

Kinerja karyawan dapat diwujudkan dalam peningkatan produksi, ketrampilan karyawan dalam menggunakan teknologi baru, dan karyawan dengan motivasi tinggi (Sultana et al., 2012). Dalam berbagai riset, terdapat beberapa faktor yang mempengaruhi efektivitas kinerja karyawan yaitu motivation (Uzonna, 2013), transformational leadership, dan organizational justice (Jankingthong dan Rurkkhum, 2012). Transformational leadership adalah faktor yang sangat berpengaruh pada kinerja karyawan karena kepemimpinan transformasional adalah tipe pemimpin yang memperhatikan kebutuhan bawahannya, mengubah keyakinan bawahan untuk mengatasi masalah dengan cara yang baru, dan mampu membangkitkan semangat bawahan agar selalu berusaha mencapai tujuan kelompok (James dan Ogbonna, 2013).

Kepemimpinan transformasional dapat mengubah keyakinan, perilaku karyawan, serta asumsi dengan menekankan pada pentingnya hasil organisasi. Dengan cara tersebut, kepemimpinan transformasional mampu mengubah keyakinan dan sikap bawahan sehingga bawahan bersedia untuk melakukan pekerjaan melebihi tingkat minimum yang telah ditentukan organisasi. Pemimpin transformasional adalah pemimpin yang karismatik. Mereka memotivasi bawahan untuk meraih cita-cita mereka dengan menanamkan nilai-nilai moral dan menginspirasi bawahan. Gaya kepemimpinan ini melibatkan penciptaan keterikatan emosional antara pemimpin dan karyawan. Pemimpin transformasional juga memperhatikan kesejahteraan karyawan mereka (Bass dan Riggio, 2006). Kepemimpinan transformasional mengintegrasikan unsur empati, kasih sayang, sensitivitas, membangun hubungan, dan inovasi (Jin, 2010). Hal tersebut dapat menumbuhkan kepercayaan karyawan dan mendorong pengembangan karyawan (Aldoory dan Toth, 2004). Kepemimpinan trasformasional juga tercermin dalam surat $\mathrm{Al}$-Anbiya ayat 73 yang berbunyi:

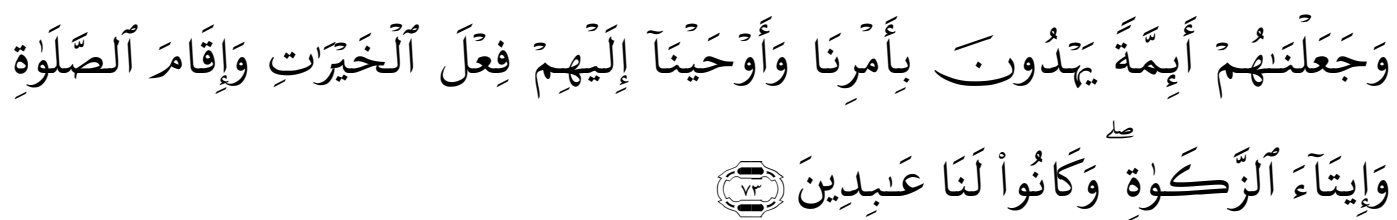

Maksud dari ayat tersebut adalah Allah SWT telah menjadikan pemimpinpemimpin yang memberi petunjuk dengan perintah Allah SWT dan telah Allah SWT wahyukan kepada para pemimpin mengerjakan kebajikan, mendirikan sembahyang, menunaikan zakat, dan hanya kepada Allah SWT para pemimpin selalu menyembah.

Menurut Bass (1985), kepemimpinan transformasional adalah suatu gaya kepemimpinan yang mempunyai empat dimensi yang disebut dengan istilah Four I's yang meliputi Pengaruh yang Ideal (Idealized Influence), Rangsangan Intelektual (Intellectual Stimulation), Pertimbangan Individu (Individualized Consideration), dan Motivasi Inspirasi (Inspirational Motivation). Karyawan dengan nalurinya merasakan adanya keharusan untuk loyal dan hormat terhadap pimpinan, dengan begitu para karyawan merasa terdorong untuk lebih giat bekerja sehingga akan meningkatkan kinerjanya. 
Penelitian Grant (2012) menunjukkan adanya pengaruh yang positif antara kepemimpinan transformasional dan kinerja karyawan. Kepemimpinan transformasional adalah tipe kepemimpinan yang paling efektif dalam memotivasi karyawan ketika karyawan memahami bahwa visi memiliki dampak yang bermanfaat bagi orang lain. Hasil tersebut konsisten dengan penelitian Cavazotte (2013) bahwa gaya kepemimpinan transformasional dapat meningkatkan kinerja karyawan dan dapat membentuk perilaku karyawan yang dapat mendorong kemajuan perusahaan di dalam konteks pekerjaan. Berbeda dengan penelitian yang dilakukan oleh Fernandes dan Awamleh (2004) dimana kepemimpinan transformasional itu sendiri tidak berpengaruh signifikan pada kinerja karyawan. Gaya alternatif kepemimpinan yang dapat diterapkan untuk meningkatkan kinerja adalah kombinasi dari gaya kepemimpinan transformasional dan gaya kepemimpinan transaksional. Hasil ini konsisten dengan penelitian Brown (2008) bahwa kepemimpinan transformasional tidak berpengaruh signifikan terhadap kinerja karyawan. Hal tersebut dipengaruhi oleh beberapa faktor antara lain tidak ada konsistensi dalam pemberian peringkat dan kurangnya komitmen karyawan.

Tidak konsistennya hasil penelitian-penelitian terdahulu mengenai pengaruh kepemimpinan transformasional pada kinerja disebabkan oleh adanya variabel pemediasi yaitu employee engagement Sandell (2012). Apabila pemimpin memahami adanya tingkat employee engagement dan kinerja dari masing-masing bawahan, maka pemimpin tersebut akan mengetahui cara terbaik untuk memimpin mereka (Sandell, 2012). Sejak diterapkannya kepemimpinan transformasional untuk mengatur organisasi lebih dari dua dekade yang lalu, banyak penelitian telah menunjukkan bahwa bawahan dari pemimpin transformasional mempunyai kinerja diatas rata-rata (Wang et al., 2011). Banyak penelitian mengenai pemimpin transformasional yang mempunyai karyawan dengan kinerja yang melampaui harapan (Bass, 1985) namun hanya beberapa teori yang menjelaskan tentang bagaimana kepemimpinan transformasional dapat mempengaruhi kinerja karyawan. Penjelasan mengapa kepemimpinan transformasional berpengaruh pada kinerja, mengarah pada konsep employee engagement, yang mengacu pada investasi pada tugas-tugas kerja individu dari atasan (Schaufeli et al., 2002; Macey dan Schneider, 2008). Menurut Blau dan Boal (1987), employee engagement mempunyai konsekuensi berupa hasil kerja, salah satunya adalah kinerja. Menurut Schaufeli dan Bakker (2003), employee engagement ditandai dengan adanya Vigor, Absorption, dan Dedication karyawan terhadap pekerjaannya. Karyawan yang memiliki employee engagement tinggi terhadap pekerjaannya ditandai dengan kepedulian yang besar terhadap tugasnya, adanya perasaan terikat secara psikologis terhadap tugas yang karyawan lakukan, dan keyakinan kuat kepada kemampuannya dalam menyelesaikan tugas. Karyawan yang memiliki fokus yang tinggi di dalam pekerjaan kantor, memiliki kinerja yang tinggi karena karyawan mempunyai kepedulian dan perasaan tanggung jawab yang besar terhadap pekerjaannya.

Hal tersebut juga terjadi pada Bank Perkreditan Rakyat Syari'ah Yogyakarta. Sebagai perusahaan yang bertugas dalam bidang jasa keuangan di Yogyakarta, karyawan BPRS diarahkan untuk meningkatkan kinerja serta etika jasa keuangan. Namun sejauh ini terdapat indikasi bahwa kinerja karyawan Bank Perkreditan Rakyat Syari'ah Yogyakarta kurang baik. Berdasarkan hasil wawancara dengan karyawan divisi sumber daya manusia Bank Perkreditan 
Rakyat Syari'ah Yogyakarta menunjukkan bahwa kurang baiknya kinerja disebabkan karena berbagai hal. Pertama, kurang tanggapnya pelayanan karyawan BPRS. Hal ini ditunjukkan dengan adanya keluhan mengenai lambannya pelayanan yang diterima pengguna jasa. Lambannya pelayanan karyawan membuktikan bahwa pekerjaan yang dilakukan oleh karyawan tidak sesuai dengan misi perusahaan yaitu memberikan layanan prima kepada nasabah dengan dukungan sumber daya manusia yang profesional. Kedua, Kualitas hasil kerja yang tidak memenuhi standar ketentuan perusahaan. Hal ini ditunjukkan dengan adanya keluhan pengguna jasa mengenai sikap karyawan yang tidak sejalan dengan prinsip Senyum, Sapa, Salam. Ketiga, kuantitas hasil kerja yang tidak mencapai target. Hal ini dibuktikan dengan kurang menariknya program yang dibuat oleh karyawan. Hal tersebut mengakibatkan tidak tercapainya target besaran dana dari nasabah yang telah ditentukan perusahaan.

Hal ini menarik perhatian penulis sehingga penulis terdorong untuk melakukan penelitian yang berjudul "Pengaruh Kepemimpinan Transformasional Terhadap Kinerja Karyawan dengan Employee Engagement sebagai Variabel Pemediasi, Studi di Bank Perkreditan Rakyat Syari'ahYogyakarta”.

\section{Metode Penelitian}

Berdasarkan permasalahan dan tujuan yang telah dirumuskan sebelumnya, maka penelitian ini berfokus pada pengaruh gaya kepemimpinan transformasional terhadap kinerja yang dimediasi employee engagement di Bank Perkreditan Rakyat Syari'ah Yogyakarta. Pada bab ini akan dijelaskan secara lebih mendalam mengenai metode penelitian yang digunakan, yaitu dengan menjabarkan pengumpulan data, analisis data, instrumen yang digunakan peneliti, dan teknik menganalisisnya dengan menggunakan teknik hierarchical regression analysis untuk mengetahui bagaimana pengaruh mediasi variabel employee engagement. Dalam model penelitian ini yang mengacu pada model Baron dan Kenny (1986).

\section{Populasi dan Sensus}

Sugiyono (2013) mengemukakan bahwa populasi dalam penelitian kuantitatif merupakan wilayah umum yang terdiri dari subyek ataupun obyek yang memiliki karakteristik tertentu yang telah ditentukan peneliti untuk dipelajari. Populasi dalam penelitian ini adalah seluruh karyawan Bank Perkreditan Rakyat Syari'ah Yogyakarta yang memenuhi kriteria tersebut. Kriteria yang ditetapkan peneliti adalah:

a. Responden merupakan karyawan dengan lama kerja lebih dari dua tahun karena telah menjadi karyawan tetap.

b. Responden merupakan karyawan dengan pendidikan terakhir minimal SMA sederajat

Melalui metode sensus, dimana populasi merupakan sampel penelitian, didapatkan jumlah karyawan yang memenuhi kriteria sebanyak 110 orang. Maka responden dalam penelitan ini berjumlah 110 orang.

\section{Teknik Pengumpulan Data}

Peneliti menggunakan teknik survei dimana peneliti berusaha mendapatkan data dari opini individu. Peneliti menyebarkan kuesioner yang berisi pertanyaanpertanyaan. Kuesioner merupakan instrumen dari sebuah survei yang dilakukan 
agar didapatkan data yang valid dan reliabel. Perusahaan memberikan rekomendasi agar peneliti dapat menyebarkan kuesioner. Kuesioner diberikan kepada divisi sumber daya manusia dan kemudian disebarkan ke seluruh karyawan perusahaan. Karena keterbatasan waktu karyawan sumber daya manusia, peneliti membantu karyawan SDM untuk menyebarkan kuesioner ke seluruh kantor Bank Perkreditan Rakyat Syari'ah Yogyakarta. Dari 110 kuesioner yang disebarkan, seluruh kuesioner kembali. Dengan demikian, tingkat pengembalian kuesioner (response rate) sebesar 100\%. Kemudian peneliti memeriksa seluruh kuesioner yang kembali untuk melihat keutuhan dan kelengkapan jawaban yang diberikan oleh responden. Hasilnya, keseluruhan kuesioner tersebut layak untuk dianalisis.

Definisi Operasional dan Pengukuran Variabel

a. Variabel Kepemimpinan Transformasional

Kepemimpinan transformasional merupakan kepemimpinan yang menanamkan intelektual anggota, memberikan dukungan moral, dan fokus terhadap visi perusahaan.

Gaya kepemimpinan transformasional menurut bass (1985) dapat diukur menggunakan empat dimensi yang disebut dengan istilah "Four I's" yaitu:

1. Idealized Influence

Idealized Influence adalah pemimpin yang menumbuhkan kepercayaan dan rasa kagum karyawan, serta pemimpin yang lebih mementingkan kepentingan orang lain dan perusahaan dari pada dirinya sendiri

2. Intellectual Stimulation

Pemimpin mampu merangsang ide baru, mampu menyelesaikan masalah dengan solusi kreatif, serta mampu memotivasi anggotanya agar dapat menggunakan pendekatan-pendekatan baru dalam menjalankan pekerjaan dalam perusahaan.

3. Individualized Consideration

Pemimpin mampu mendengarkan serta memperhatikan masukan anggotanya, berusaha memenuhi kebutuhan anggota dalam mengembangkan karirnya, serta membimbing dan melatih anggotanya secara pribadi.

4. Inspirational Motivation

Pemimpin mampu menginspirasi anggotanya agar mereka merasa yakin dapat menyelesaikan pekerjaan yang telah dilimpahkan dan mampu memberikan gagasan. Karyawan secara tidak langsung termotivasi oleh pemimpinnya.

Penyusunan kuesioner untuk mengukur variabel kepemimpinan transformasional menggunakan angket berdasarkan Multifactor Leadership Questionnaire (MLQ) yang disusun oleh Avolio et al (1999) yang telah dimodifikasi. Item kuesioner untuk variabel kepemimpinan transformasional berjumlah 20 item.

b. Variabel Kinerja Karyawan

Kinerja Karyawan merupakan hasil kerja karyawan setelah melakukan usaha berdasarkan kemampuan yang dimiliki karyawan selama periode tertentu. Berdasarkan penelitian oleh Welbourne et al. (1998) indikator kinerja kayawan adalah: 
1. Job

Karyawan melakukan hal-hal khusus terkait dengan job descripton dari masing-masing karyawan.

2. Career

Karyawan dapat memperoleh keterampilan yang diperlukan untuk masa depannya melalui sebuah organisasi.

3. Innovator

Karyawan diharapkan untuk berkreasi dan berinovasi dalam menyelesaikan pekerjaan secara individu dan secara organisasi

4. Team

Bekerja dengan rekan kerja dan anggota tim untuk keberhasilan perusahaan.

5. Organization

Karyawan melaksanakan tugasnya sebagai bentuk dedikasi untuk kemajuan perusahaan.

Dalam penyusunan kuesioner, untuk mengukur variabel kinerja penulis menggunakan angket yang dikembangkan oleh Welbourne et al. (1998) yang telah dimodifikasi. Item kuesioner berjumlah 20 item. Dimensi kinerja karyawan dalam instrument meliputi job, career, innovator, team, dan organization.

a. Variabel Employee Engagement

Employee engagement adalah keterikatan karyawan secara fisik dan emosional dengan pekerjaanya. Karyawan akan merasa lebih peduli dan termotivasi untuk menyukseskan perusahaannya. Dalam penyusunan kuesioner, penulis mengembangkan penelitian yang dilakukan Schaufeli dan Bakker (2003), terdapat tiga instrumen employee engagement yaitu Vigor, Absorption, dan Dedication.

1. Vigor

Kekuatan dan ketahanan mental di dalam konteks pekerjaan serta kemauan dalam berusaha dan bertahan dalam menghadapi suatu tantangan.

2. Absorption

Mampu berkonsentrasi penuh pada suatu pekerjaan dan merasa bahagia dalam melaksanakan pekerjaan. Saat bekerja waktu juga menjadi lebih cepat.

3. Dedication

Perasaan antusias, bangga terhadap pekerjaan, dan tertantang di tempat kerja.

Indikator tersebut dijadikan titik tolak untuk menyusun item instrumen berupa pertanyaan. Item instrument yang mengukur tingkat employee engagement adalah 17 pertanyaan. Item instrument tersebut diukur menggunakan skala Likert sebagai berikut:

Sangat setuju dengan nilai 5

Setuju dengan nilai 4

Netral dengan nilai 3

Tidak setuju dengan nilai 2

Sangat tidak setuju dengan nilai 1

Pengujian Instrumen

a. Uji Validitas 
Uji Validitas adalah uji yang digunakan untuk mengetahui sah atau tidaknya sebuah alat ukur digunakan untuk mengukur apa yang seharusnya diukur (Jogiyanto, 2010). Pengukuran dikatakan valid jika mengukur tujuan dengan nyata atau benar. Alat ukur tidak valid apabila memberikan hasil ukuran yang menyimpang dari tujuan (error) (Jogiyanto, 2010). Dalam penelitian ini hanya dilakukan uji validitas validitas isi (content validity) yaitu yaitu validitas yang menunjukkan tingkat seberapa besar itemitem kuesioner dapat mewakili atau menggambarkan konsep yang akan diukur (Jogiyanto, 2010), karena kuesioner telah digunakan pada penelitian sebelumnya dan sudah terstandarisasi. Peneliti juga melakukan uji validitas muka (face validity) dimana instrument yang digunakan untuk mengukur apa yang seharusnya diukur dievaluasi oleh ahli.

b. Uji Reliabilitas

Uji reliabilitas adalah uji untuk mengukur tingkat kemampuan suatu instrument penelitian dalam pengumpulan data secara konsisten dari karyawan. Suatu instrumen dikatakan reliabel apabila jika instrument tersebut apabila digunakan kembali, hasilnya tetap sama. Agar dapat melihat instrument tersebut reliabel atau tidak peneliti melihat table Cronbach alpha. Sekaran dan Bougie (2013) mengkategorikan nilai Cronbach's alpha sebagai berikut:

Cronbach's alpha 0.8-1.0 : reliabilitas baik

Cronbach's alpha 0.6-0.7 : reliabilitas dapat diterima

Cronbach's alpha $<0,6 \quad$ : reliabilitas kurang baik.

Pengujian Hipotesis

Pengujian hipotesis dilakukan dengan teknik hierarchical regression analysis berdasarkan pada model Baron dan Kenny (1986). Teknik ini digunakan untuk pengaruh antar variabel dan pemediasi suatu variabel. Konsep ini dipilih karena telah mencakup langkah-langkah statistik yang menunjukkan bahwa suatu variabel memiliki pengaruh mediasi secara penuh, sebagian, atau tidak memiliki pengaruh mediasi sama sekali.

Variabel dapat dikatakan berfungsi sebagai variabel pemediasi apabila memenuhi persyaratan atau kondisi sebagai berikut:

a. Variabel kepemimpinan transformasional yang awalnya berpengaruh signifikan menjadi tidak berpengaruh signifikan terhadap variabel kinerja setelah variabel employee engagement dikontrol, maka pengaruh pemediasi penuh (fullymediated) akan terjadi.

b. Apabila signifikansi variabel kepemimpinan transformasional meningkat atau menurun terhadap variabel kinerja setelah employee engagement dikontrol, maka akan terjadi pemediasi sebagian (partially-mediated).

Langkah-langkah yang harus dilakukan untuk menguji variabel pemediasi dalam penelitian ini adalah sebagai berikut:

Analisis regresi variabel kepemimpinan transformasional $(\mathrm{X})$ dengan variabel kinerja $(\mathrm{Y})$ :

$\mathrm{Y}=\mathrm{B}_{0}+\mathrm{B}_{1} \mathrm{X}+\mathrm{e}$

Analisis regresi variabel kepemimpinan transformasional $(\mathrm{X})$ dengan variabel employee engagement $(\mathrm{Y})$ :

$\mathrm{M}=\mathrm{B}_{0}+\mathrm{B}_{1} \mathrm{X}+\mathrm{e}$

Analisis regresi variabel employee engagement $(\mathrm{M})$ dengan variabel kinerja $(\mathrm{Y})$ :

$\mathrm{Y}=\mathrm{B}_{0}+\mathrm{B}_{1} \mathrm{M}+\mathrm{e}$

Analisis regresi variabel kepemimpinan transformasional $(\mathrm{X})$ dengan variabel employee engagement $(\mathrm{M})$ untuk memprediksi variabel kinerja $(\mathrm{Y})$ :

$\mathrm{Y}=\mathrm{B}_{0}+\mathrm{B}_{1} \mathrm{X}+\mathrm{B}_{2} \mathrm{M}+\mathrm{e}$ 


\section{Pembahasan}

a. Karakteristik responden

Karakteristik responden dalam penelitian ini meliputi jenis kelamin, umur, pendidikan, dan lama kerja yang disajikan dalam Tabel 2. Selain karakteristik para responden, dalam tabel tersebut juga menunjukkan deskripsi tanggapan dari masing-masing pernyataan dalam kuesioner yaitu kepemimpinan transformasional, kinerja karyawan, dan employee engagement berdasarkan jenis kelamin, umur, pendidikan, dan lama kerja . Interval dalam deskripsi tanggapan ditentukan dengan menggunakan rumus (Lind et al., 2015):

$\mathrm{i}=\frac{\mathrm{H}-\mathrm{L}}{\mathrm{K}}$

Keterangan:

$\mathrm{i} \quad=$ Interval kelas

$\mathrm{H}=$ Skor tertinggi

$\mathrm{L}=$ Skor terendah

$\mathrm{K}$ = Banyaknya kelas

Dengan menggunakan rumus interval kelas, maka diperoleh interval kelas sebagai

berikut:

$\mathrm{i}=\frac{\mathrm{H}-\mathrm{L}}{\mathrm{K}}$

$\mathrm{i}=\frac{5-1}{5}$

$\mathrm{i}=0,8$

Berdasarkan interval kelas tersebut maka dapat ditentukan klasifikasi masingmasing

komponen kepemimpinan transformasional, kinerja karyawan, dan employee engagement sebagai berikut:

Tabel 1 Klasifikasi Tanggapan Komponen transformasional, kinerja karyawan, dan

\begin{tabular}{|l|l|}
\multicolumn{2}{c}{ employee engagement } \\
\hline Kategori & Interval \\
\hline Sangat Rendah & $1,00-1,80$ \\
\hline Rendah & $1,81-2,60$ \\
\hline Sedang & $2,61-3,40$ \\
\hline Tinggi & $3,41-4,20$ \\
\hline Sangat Tinggi & $4,21-5,00$ \\
\hline
\end{tabular}

Sumber: Data primer yang diolah, 2019

Kemudian, menentukan skor responden dengan menjumlahkan total jawaban dari seluruh tiap item pernyataan antara skor (1) sampai dengan skor (5) kemudian dibagi dengan jumlah responden yang telah dikalikan jumlah pernyataan yang digolongkan berdasarkan jenis kelamin, umur, pendidikan, dan lama kerja. Berdasarkan interval tersebut, maka dapat diklasifikasikan tingkat kepemimpinan transformasional, kinerja karyawan, dan employee engagement dari responden. 
Tabel 2. Karekteristik Responden

\begin{tabular}{|l|l|l|l|l|l|l|l|}
\hline No. & Karakteristik & Kategori & Jumlah & Persentase (\%) & KT & KK & EE \\
\hline 1. & Jenis Kelamin & Laki-laki & 56 & 50,9 & 4,02 & 4,10 & 4,05 \\
\hline & & Wanita & 54 & 49,1 & 4,06 & 4,13 & 4,00 \\
\hline 2. & Umur & $<30$ tahun & 44 & 40 & 4,14 & 4,18 & 4,05 \\
\hline & & $30-35$ tahun & 30 & 27,27 & 4,09 & 4,22 & 4,08 \\
\hline & & $36-40$ tahun & 18 & 16,36 & 4,13 & 4,23 & 4,12 \\
\hline & & $41-45$ tahun & 7 & 6,37 & 4,09 & 4,11 & 4,19 \\
\hline & & $46-50$ tahun & 3 & 2,73 & 4,13 & 4,20 & 4,06 \\
\hline & & $>50$ tahun & 8 & 7,27 & 4,11 & 4,18 & 4,14 \\
\hline 3. & Pendidikan & SMA/Sederajat & 24 & 21,82 & 4,18 & 4,21 & 4,09 \\
\hline & & D1 & 0 & 0 & - & - & - \\
\hline & & D2 & 1 & 0,91 & 4,94 & 4,35 & 4,24 \\
\hline & & D3 & 17 & 15,45 & 4,06 & 4,12 & 4,06 \\
\hline & & S1 & 63 & 57,27 & 4,12 & 4,21 & 4,10 \\
\hline & & S2 & 5 & 4,55 & 4,06 & 4,15 & 3,94 \\
\hline 4. & Lama Kerja & $3-5$ tahun & 54 & 49,1 & 3,45 & 3,50 & 3,38 \\
\hline & & $>5$ tahun & 56 & 50,9 & 4,77 & 4,87 & 4,77 \\
\hline
\end{tabular}

Sumber: Data primer yang diolah, 2019

Keterangan:

KT = Kepemimpinan Transformasional

$\mathrm{KK}=$ Kinerja Karyawan

$\mathrm{EE}=$ Employee engagement

Jenis Kelamin Responden

Berdasarkan jenis kelamin, responden dibagi menjadi dua yaitu laki-laki dan wanita. Jumlah responden laki laki di Bank Perkreditan Rakyat Syari'ah Yogyakarta adalah 56 dengan persentase 50,9 persen dan jumlah responden wanita di perusahaan adalah 54 dengan persentase 49,1 persen. Hal ini menunjukkan bahwa jumlah responden di perusahaan didominasi oleh laki-laki.

Pada Tabel 2 juga menunjukkan bahwa tingkat kepemimpinan transformasional, kinerja karyawan, serta employee engagement berjenis kelamin laki-laki dan perempuan berada pada kategori tinggi.

Umur Responden

Peneliti membagi umur responden menjadi 6 kategori yaitu $<30$ tahun, $30-35$ tahun, 30 - 35 tahun, 36 - 40 tahun, $41-45$ tahun, $46-50$ tahun, dan $>50$ tahun. Mayoritas umur responden adalah kurang dari 30 tahun dengan jumlah 44 karyawan dan persentasi 40 persen. Responden dengan umur 30 - 35 tahun berjumlah 30 dengan persentase 27,27 persen. Responden dengan umur $36-40$ tahun berjumlah 18 dengan persentase 16,36 persen. Responden dengan umur 41 - 45 tahun berjumlah 7 dengan persentase 6,37 persen. Responden dengan umur lebih dari 50 tahun tahun berjumlah 8 dengan persentase 7,27 persen. Responden dengan umur minoritas adalah responden dengan kategori umur 46 - 50 tahun dengan jumlah 3 karyawan dan persentase 2,73 Hal ini membuktikan bahwa karyawan perusahaan mempunyai potensi untuk lebih meningkatkan kinerjanya.

Data juga menunjukkan bahwa tingkat kepemimpinan transformasional dan employee engagement masuk dalam kategori tinggi. Responden yang berusia 3040 cenderung memiliki tingkat kinerja yang sangat tinggi dan yang lainnya cenderung memiliki kinerja yang tinggi. 


\section{Pendidikan Responden}

Mayoritas responden mempunyai pendidikan terakhir S1 dengan jumlah 63 dan persentase 57,27 persen. Responden dengan pendidikan terakhir SMA/sederajat sebanyak 24 dengan persentase 21,82 persen. Tidak ada responden dengan pendidikan terakhir D1. Responden dengan pendidikan terakhir D2 sebanyak 1 dengan persentase 0,91 persen. Responden dengan pendidikan terakhir D3 sebanyak 17 dengan persentase 15,45 persen dan responden dengan pendidikan terakhir S2 sejumlah 5 dan dengan persentase 4,55 persen. Hal tersebut menunjukkan bahwa karyawan di perusahaan mempunyai pendidikan terakhir yang cukup tinggi sehingga mempunyai pengetahuan dan ketrampilan untuk mengemban tugasnya sesuai dengan job description masing-masing karyawan.

Data juga menunjukkan bahwa tingkat kepemimpinan transformasional, untuk responden dengan pendidikan terakhir D2 masuk dalam kategori sangat tinggi, sedangkan responden yang lain masuk dalam kategori tinggi. Tingkat kinerja karyawan untuk responden dengan pendidikan terakhir SMA/sederajat, D2, dan S1 masuk dalam kategori sangat tinggi sedangkan yang lainnya masuk dalam kategori tinggi. Tingkat employee engagement untuk responden dengan pendidikan terakhir D2 masuk dalam kategori sangat tinggi, sedangkan responden yang lain masuk dalam kategori tinggi.

\section{Lama Kerja Responden}

Berdasarkan data responden yang diperoleh, responden yang telah bekerja selama 3 sampai 5 tahun berjumlah 54 dan dengan persentase 49,1 persen dan responden yang telah bekerja lebih dari 5 tahun berjumlah 56 dan dengan persentase 50,9 persen.

Data juga menunjukkan bahwa tingkat kepemimpinan transformasional dan kinerja karyawan untuk responden dengan lama kerja 3 - 5 tahun masuk dalam kategori tinggi, sedangkan tingkat employee engagement masuk dalam kategori sedang. Untuk responden dengan lama kerja lebih dari 5 tahun, memiliki tingkat kepemimpinan transformasional, kinerja karyawan, dan employee engagement yang sangat tinggi.

\section{Hasil Uji Instrumen}

a. Hasil Uji Validitas

Peneliti menggunakan kuesioner yang telah terstandarisasi karena telah digunakan untuk penelitian terdahulu. Uji yang digunakan untuk mengukur terhadap apa yang harus diukur adalah dengan menggunakan uji content validity, yaitu uji yang hanya menunjukkan tingkat item dalam kuesioner yang dapat mewakili konsep yang diukur (Jogiyanto, 2010). Penelitian ini tidak melakukan uji validitas konstruk pada instrumen penelitian, karena kuesioner yang digunakan telah terstandarisasi. Selain itu, kuesioner yang digunakan telah diadopsi oleh beberapa peneliti sebelumnya. Kuesioner yang digunakan sudah mencakup topik yang sudah didefinisikan sebagai dimensi-dimensi dan elemen-elemen yang relevan menggambarkan konsep penelitian, maka dapat dikatakan bahwa instrument tersebut mempunyai validitas isi. Selain itu peneliti juga menggunakan face falidity dimana menurut ahli, instrumen yang digunakan telah memenuhi standar untuk mengukur apa yang seharusnya diukur.

b. Hasil Uji Reliabilitas 
Uji reliabilitas digunakan untuk mengukur tingkat kemampuan suatu instrument penelitian dalam pengumpulan data secara konsisten dari karyawan. Reliabel atau tidaknya suatu instrument dapat dilihat dari kolom Cronbach alpha. Berikut ini adalah hasil uji reliabilitas.

Tabel 3 Hasil Uji Reliabilitas Kepemimpinan Transfomasional

\begin{tabular}{|c|c|c|c|}
\hline Variabel & $\begin{array}{l}\text { Hasil Uji Reliabilitas } \\
\text { Cronbachs Alpha }\end{array}$ & Item Pertanyaan & $\begin{array}{l}\text { Cronbach's Alpha if } \\
\text { Item Deleted }\end{array}$ \\
\hline \multirow{20}{*}{$\begin{array}{l}\text { Kepemimpinan } \\
\text { Transformasional }\end{array}$} & \multirow[t]{20}{*}{0,784} & KT1 & 0,773 \\
\hline & & KT2 & 0,772 \\
\hline & & KT3 & 0,776 \\
\hline & & KT4 & 0,776 \\
\hline & & KT5 & 0,774 \\
\hline & & KT6 & 0,772 \\
\hline & & KT7 & 0,771 \\
\hline & & KT8 & 0,763 \\
\hline & & KT9 & 0,771 \\
\hline & & KT10 & 0,772 \\
\hline & & KT11 & 0,770 \\
\hline & & KT12 & 0,775 \\
\hline & & KT13 & 0,780 \\
\hline & & KT14 & 0,772 \\
\hline & & KT15 & 0,779 \\
\hline & & KT16 & 0,783 \\
\hline & & KT17 & 0,771 \\
\hline & & KT18 & 0,775 \\
\hline & & KT19 & 0,779 \\
\hline & & KT20 & 0,790 \\
\hline
\end{tabular}

Sumber: Data primer yang diolah, 2019

Dari tabel di atas dapat diketahui bahwa nilai Cronbach's Alpha dari item-item pertanyaan variabel kepemimpinan transformasional (X) lebih dari 0,6. Hal ini menunjukkan bahwa butir-butir pertanyaan dalam kuesioner yang dibagikan reliabel.

Tabel 4 Hasil Uji Reliabilitas Kinerja Karyawan

\begin{tabular}{|c|c|c|c|}
\hline Variabel & $\begin{array}{l}\text { Hasil Uji Reliabilitas } \\
\text { Cronbachs Alpha }\end{array}$ & Item Pertanyaan & $\begin{array}{l}\text { Cronbach's Alpha if } \\
\text { Item Deleted }\end{array}$ \\
\hline \multirow[t]{20}{*}{ Kinerja Karyawan } & \multirow[t]{20}{*}{0,862} & KK1 & 0,857 \\
\hline & & KK2 & 0,859 \\
\hline & & KK3 & 0,860 \\
\hline & & KK4 & 0,863 \\
\hline & & KK5 & 0,855 \\
\hline & & KK6 & 0,857 \\
\hline & & KK7 & 0,855 \\
\hline & & KK8 & 0,851 \\
\hline & & KK9 & 0,858 \\
\hline & & KK10 & 0,854 \\
\hline & & KK11 & 0,859 \\
\hline & & KK12 & 0,855 \\
\hline & & KK13 & 0,852 \\
\hline & & KK14 & 0,852 \\
\hline & & KK15 & 0,852 \\
\hline & & KK16 & 0,852 \\
\hline & & KK17 & 0,853 \\
\hline & & KK18 & 0,857 \\
\hline & & KK19 & 0,861 \\
\hline & & KK20 & 0,859 \\
\hline
\end{tabular}


Dari tabel di atas dapat diketahui bahwa nilai Cronbach's Alpha dari item-item pertanyaan variabel kinerja karyawan (Y) lebih dari 0,6. Hal ini menunjukkan bahwa butir-butir pertanyaan dalam kuesioner yang dibagikan reliabel.

Tabel 5 Hasil Uji Reliabilitas Employee Engagement

\begin{tabular}{|c|c|c|c|}
\hline Variabel & $\begin{array}{l}\text { Hasil Uji Reliabilitas } \\
\text { Cronbachs Alpha }\end{array}$ & Item Pertanyaan & $\begin{array}{l}\text { Cronbach's Alpha if } \\
\text { Item Deleted }\end{array}$ \\
\hline \multirow[t]{17}{*}{ Employee Engagement. } & \multirow{17}{*}{0,802} & EE1 & 0,785 \\
\hline & & EE2 & 0,790 \\
\hline & & EE3 & 0,798 \\
\hline & & EE4 & 0,800 \\
\hline & & EE5 & 0,786 \\
\hline & & EE6 & 0,791 \\
\hline & & EE7 & 0,794 \\
\hline & & EE8 & 0,788 \\
\hline & & EE9 & 0,793 \\
\hline & & EE10 & 0,789 \\
\hline & & EE11 & 0,783 \\
\hline & & EE12 & 0,792 \\
\hline & & EE13 & 0,809 \\
\hline & & EE14 & 0,787 \\
\hline & & EE15 & 0,793 \\
\hline & & EE16 & 0,792 \\
\hline & & EE17 & 0,802 \\
\hline
\end{tabular}

Sumber: Data primer yang diolah, 2019

Dari tabel di atas dapat diketahui bahwa nilai Cronbach's Alpha dari itemitem pertanyaan variabel employee engagement (M) lebih dari 0,6. Hal ini menunjukkan bahwa butir-butir pertanyaan dalam kuesioner yang dibagikan reliabel.

Analisis Statistik Deskriptif

Analisis statistik deskriptif berfungsi untuk mendeskripsikan keadaan suatu gejala yang telah diukur kemudian diolah sesuai dengan fungsinya. Hasil pengolahan tersebut selanjutnya dipaparkan dalam bentuk angka sehingga akan lebih mudah untuk ditangkap maknanya oleh siapapun yang membutuhkan informasi tentang data yang diperoleh. Penyajian data dilakukan dengan mencari ukuran tendensi sentralnya, dalam hal ini yang digunakan peneliti adalah nilai rata-rata (mean) (Arikunto, 1993:363). Analisis statistik deskriptif diperoleh dengan mengelompokkan data kemudian menjumlahkan data seluruh individu dalam kelompok dan selanjutnya dibagi dengan jumlah individu yang berada dalam satu kelompok.

Nilai mean variabel kepemimpinan transformasional adalah sebagai berikut:

Tabel 6 Nilai Rata-rata Kepemimpinan Transformasional

\begin{tabular}{|r|r|r|r|}
\hline No. & Dimensi & No. Item & Rata-rata \\
\hline 1. & Idealized Influence & $1,2,3,4,5$ & 4,07 \\
\hline 2. & Inspirational Motivation & $6,7,8,9,10$ & 4,17 \\
\hline 3. & Intellectual Stimulation & $11,12,13,14,15$ & 4,15 \\
\hline 4. & Individualized Consideration & $16,17,18,19,20$ & 4,07 \\
\hline 5. & \multicolumn{2}{|c|}{ Kepemimpinan Transformasional } & 4,12 \\
\hline
\end{tabular}

Sumber: Data primer yang diolah, 2019

Hasil analisis deskriptif pada variabel kepemimpinan transformasional menunjukkan bahwa skor rata-rata jawaban responden adalah tinggi $(4,12)$. Hal ini berarti bahwa pemimpin yang ada pada Kantor Bank Perkreditan Rakyat Syari'ah Yogyakarta telah mampu memberikan motivasi inspiratif, pengaruh yang 
ideal, pertimbangan individu, dan stimulasi intelektual kepada pengikutnya agar bersedia bekerja sesuai dengan tujuan-tujuan yang lebih tinggi sesuai dengan yang diharapkan. Skor rata-rata jawaban responden pada dimensi Idealized Influence adalah tinggi (4,07). Pemimpin Kantor Bank Perkreditan Rakyat Syari'ah Yogyakarta Yogyakarta telah mampu memberikan contoh untuk lebih mengedepankan kepentingan perusahaan dari pada diri sendiri demi kepentingan bersama, mempertimbangkan etika dan moral saat mengambil keputusan serta memberikan rasa percaya diri dan penghargaan kepada pengikutnya saat bekerja sehingga karyawan dapat lebih menghormati pimpinan dan lebih termotivasi untuk bekerja.

Skor rata-rata jawaban responden pada dimensi kedua ditafsirkan tinggi $(4,17)$. Pemimpin Kantor Bank Perkreditan Rakyat Syari'ah Yogyakarta telah mampu memberikan motivasi, kepada karyawan bahwa visi perusahaan dapat dicapai. Pemimpin juga memotivasi karyawan, menjelaskan tentang tujuan organisasi, dan membesarkan hati karyawan sehingga dapat bekerja lebih giat.

Skor rata-rata jawaban responden pada dimensi Intellectual Stimulation adalah tinggi $(4,15)$. Hal ini berarti bahwa pemimpin di Kantor Bank Perkreditan Rakyat Syari'ah Yogyakarta Yogyakarta telah mampu merangsang bawahannya untuk lebih inovatif, salah satu caranya adalah dengan memberikan pekerjaan-pekerjaan baru yang lebih menantang kepada para bawahannya. Selain itu, mereka juga dituntut mampu mencari jalan keluar saat terjadi masalah dengan pendekatan baru.

Skor rata-rata jawaban responden pada dimensi Individualized Consideration adalah tinggi (4,07). Hal ini berarti bahwa pemimpin Kantor Bank Perkreditan Rakyat Syari'ah Yogyakarta memberikan keterbukaan dengan adanya kesalahan dan penyimpangan dari standar yang sudah ditetapkan sebelumnya. Sebagai contoh, pemimpin dengan sabar memberikan bimbingan dan arahan kepada bawahan agar tidak terjadi kesalahan yang kedua.

Dengan mengamati nilai rata-rata per dimensi, maka dapat disimpulkan bahwa penilaian terendah terdapat pada dimensi Idealized Influence dan individual consideration. Hal ini artinya pemimpin harus lebih mempertimbangkan etika dan moral saat mengambil keputusan serta lebih memberikan rasa percaya diri pada karyawan. Keterbukaan dan kesempatan yang diberikan pemimpin kepada bawahannya walaupun sudah baik, masih tetap merupakan salah satu dari dimensi kepemimpinan transformasional yang paling rendah. Dengan kata lain, keterbukaan dan peluang yang diberikan pemimpin Bank Perkreditan Rakyat Syari'ah Yogyakarta kepada para bawahan untuk berbuat sesuatu yang berbeda dari standar masih perlu ditingkatkan dan belum optimal.

Nilai mean variabel kinerja karyawan adalah sebagai berikut:

Tabel 7 Nilai Rata-rata Kinerja Karyawan

\begin{tabular}{|l|l|l|l|}
\hline No. & Dimensi & No. Item & Rata-rata \\
\hline & Job & $1,2,3,4$ & 4,17 \\
\hline & Career & $5,6,7,8$ & 4,19 \\
\hline & Innovator & $9,10,11,12$ & 4,17 \\
\hline & Team & $13,14,15,16$ & 4,24 \\
\hline & Organization & $17,18,19,20$ & 4,21 \\
\hline & Kinerja Karyawan & 4,20 \\
\hline
\end{tabular}

Sumber: Data primer yang diolah, 2019 
Hasil analisis deskriptif pada variabel kinerja karyawan menunjukkan bahwa skor rata-rata jawaban responden adalah tinggi $(4,20)$. Hal ini berarti bahwa karyawan mempunyai hasil kerja yang cukup baik setelah melakukan usaha berdasarkan kemampuan yang dimiliki karyawan selama periode tertentu.

Skor rata-rata jawaban responden pada dimensi job adalah tinggi $(4,17)$. Hal ini menunjukkan bahwa karyawan telah bekerja sesuai dengan job descripton dari masing-masing karyawan.

Skor rata-rata jawaban responden pada dimensi Career adalah sebesar $(4,19)$. Hal ini mennjukkan bahwa karyawan telah berusaha untuk mengembangkan karirnya yakni mendapatkan tujuan karir pribadi, mengembangkan keterampilan yang dibutuhkan untuk karir di masa depannya, membuat kemajuan dalam karirnya, dan mencari peluang karir.

Skor rata-rata jawaban responden pada dimensi Innovator adalah sebesar $(4,17)$. Hal ini menunjukkan bahwa karyawan telah berinovasi dalam menyelesaikan pekerjaan secara individu dan organisasi secara keseluruhan. Karyawan mempunyai ide-ide baru, bekerja dengan menerapkan ide-ide baru, menemukan ide baru untuk menyelesaikan masalah dalam pekerjaannya serta membuat proses yang lebih baik dalam rutinitas kerja.

Skor rata-rata jawaban responden pada dimensi Innovator adalah sebesar $(4,24)$. Hal ini menunjukkan bahwa karyawan telah bekerja sebagai bagian dari kelompok tim, mencari informasi dari orang lain untuk pekerjaan kelompok, membuat keyakinan bahwa kelompok kerjanya berhasil, serta menanggapi kebutuhan orang lain di dalam kelompok kerjanya.

Skor rata-rata jawaban responden pada dimensi Organization adalah sebesar $(4,21)$. Hal ini menunjukkan bahwa karyawan telah melakukan hal-hal untuk membantu orang lain walaupun bukan bagian dari pekerjaannya, bekerja untuk kebaikan perusahaan, melakukan hal-hal untuk mempromosikan perusahaan, dan membantu perusahaan sehingga perusahaan menjadi lebih baik.

Dengan mengamati nilai rata-rata per dimensi, maka dapat disimpulkan bahwa penilaian terendah terdapat pada dimensi Job dan Innovator. Hal ini berarti bahwa karyawan harus lebih meningkatkan kinerjanya yang terkait dengan jumlah output kerja, kualitas output kerja, akurasi kerja, serta peran karyawan untuk rekan kerjanya dalam menyelesaikan pekerjaan. Karyawan juga harus lebih berfikir kreatif dalam menyelesaikan masalah dalam pekerjaannya.

Nilai mean variabel kinerja karyawan adalah sebagai berikut:

Tabel 8 Nilai Rata-rata Employee Engagement

\begin{tabular}{|l|l|l|l|}
\hline No. & Dimensi & No. Item & Rata-rata \\
\hline & Vigor & $1,2,3,4,5,6$ & 4,13 \\
\hline & Dedication & $7,8,9,10,11$ & 4,10 \\
\hline & Absorption & $12,13,14,15,16,17$ & 4,03 \\
\hline & Employee Engagement & 4,09 \\
\hline
\end{tabular}

Sumber: Data primer yang diolah, 2019

Hasil analisis deskriptif pada variabel employee engagement menunjukkan bahwa skor rata-rata jawaban responden adalah tinggi (4,09). Hal ini menunjukkan bahwa karyawan telah menggunakan fisik, kognitif dan emosionalnya untuk berperan dalam pekerjaannya.

Skor rata-rata jawaban responden pada dimensi vigor adalah tinggi $(4,13)$. Hal ini menunjukkan bahwa karyawan mempunyai tingkat kekuatan dan tingkat 
resiliensi mental yang cukup tinggi dalam bekerja, keinginan untuk berusaha dengan semaksimal mungkin di dalam pekerjaan, gigih dalam menghadapi kesulitan dalam bekerja.

Skor rata-rata jawaban responden pada dimensi dedication adalah tinggi $(4,10)$. Hal ini menunjukkan bahwa karyawan mampu mengidentifikasi pekerjaan mereka karena menjadikannya pengalaman berharga, menginspirasi dan menantang. Selain itu, karyawan merasa antusias dan bangga pada pekerjaan mereka.

Skor rata-rata jawaban responden pada dimensi absorption adalah tinggi (4,03). Hal ini menunjukkan bahwa karyawan merasa senang dengan pekerjaannya, merasa tenggelam dalam pekerjaan dan sulit untuk memisahkan diri dari pekerjaan. Dengan mengamati nilai rata-rata per dimensi, maka dapat disimpulkan bahwa penilaian terendah terdapat pada dimensi absorption. Hal ini berarti karyawan harus lebih meningkatkan konsentrasi dan minat yang kuat pada pekerjaannya.

Pengujian Hipotesis

Sesuai dengan prosedur yang disarankan oleh Baron dan Kenny (1986), untuk membuktikan bahwa employee engagement memiliki peran mediator antara hubungan pengaruh kepemimpinan transformational pada kinerja karyawan. Sehinga akan dilakukan 2 perhitungan regresi, yaitu: Pertama akan dilakukan regresi terhadap path koefesien untuk jalur-jalur independen terhadap variabel yang diteliti. Kemudian dilakukan perhitungan untuk memastikan pengaruh antara kepemimpinan transformasional dan kinerja karyawan apabila employee engagement dimasukan dalam perhitungan. Langkah-langkah pengujian hipotesis adalah sebagai berikut:

\begin{tabular}{|c|c|c|c|c|c|c|}
\hline \multirow{3}{*}{ Variabel Independen } & \multicolumn{6}{|c|}{ Variabel Dependen } \\
\hline & \multicolumn{3}{|c|}{ Employee Engagement } & \multicolumn{3}{|c|}{ Kinerja Karyawan } \\
\hline & B & $\mathrm{T}$ & $\mathrm{Sig}$ & B & $\mathrm{T}$ & Sig \\
\hline $\begin{array}{l}\text { Langkah 1: } \\
\text { Kepemimpinan } \\
\text { Transformasional } \\
\mathrm{R}^{2}=0,429 \\
\mathrm{~F}=81,215\end{array}$ & & & & 0,655 & 9,012 & 0,00 \\
\hline $\begin{array}{l}\text { Langkah 2: } \\
\text { Kepemimpinan } \\
\text { Transformasional } \\
\mathrm{R}^{2}=0,394 \\
\mathrm{~F}=70,342\end{array}$ & 0,628 & 8,387 & 0,000 & & & \\
\hline $\begin{array}{l}\text { Langkah 3: } \\
\text { Employee Engagement } \\
\mathrm{R}^{2}=0,412 \\
\mathrm{~F}=75,669\end{array}$ & & & & 0,642 & 8,699 & 0,00 \\
\hline $\begin{array}{l}\text { Langkah 4: } \\
\text { Employee Engagement } \\
\text { Kepemimpinan } \\
\text { Transformasional } \\
\mathrm{R}^{2}=0,517 \\
\mathrm{~F}=50,876\end{array}$ & & & & $\begin{array}{l}0,380 \\
0,416\end{array}$ & $\begin{array}{l}4,406 \\
4,820\end{array}$ & 0,00 \\
\hline
\end{tabular}


Sumber: Data primer yang diolah, 2019

Tabel 9 menunjukkan hasil analisis regresi pada setiap langkah yang dapat dijelaskan sebagai berikut:

Langkah 1, hasil menunjukkan bahwa kepemimpinan transformasional berpengaruh secara positif dan signifikan pada kinerja karyawan $(\beta=0,655 ; \mathrm{t}=$ 9,021; $\mathrm{p}<0,05)$. Ini berarti hipotesis 1 didukung, yaitu kepemimpinan transformasional berpengaruh positif pada kinerja karyawan. Koefisien determinasi $\left(\mathrm{R}^{2}\right)$ sebesar 0,429 menunjukkan bahwa 42,9\% variasi variabel kinerja karyawan dapat dijelaskan oleh variabel kepemimpinan transformasional, sedangkan $57,1 \%$ dijelaskan oleh variabel atau faktor lain.

Langkah 2, hasil analisis regresi menunjukkan bahwa kepemimpinan transformasional berpengaruh positif dan signifikan pada employee engagement ( $\beta$ $=0,628 ; \mathrm{t}=8,387 ; \mathrm{p}<0,05)$. Ini berarti hipotesis 2 didukung, yaitu kepemimpinan transformasional berpengaruh positif dan signifikan pada employee engagement. Koefisien determinasi $\left(\mathrm{R}^{2}\right)$ sebesar 0,394 menunjukkan bahwa $39,4 \%$ variasi variabel employee engagement dapat dijelaskan oleh variabel kepemimpinan transformasional, sedangkan $60,6 \%$ dijelaskan oleh variabel atau faktor lain.

Langkah 3, hasil analisis regresi menunjukkan bahwa employee engagement berpengaruh positif dan signifikan pada kinerja karyawan $(\beta=0,642 ; \mathrm{t}$ $=8,699 ; \mathrm{p}<0,05)$. Ini berarti hipotesis 3 didukung, yaitu employee engagement berpengaruh positif dan signifikan pada kinerja karyawan. Koefisien determinasi $\left(\mathrm{R}^{2}\right)$ sebesar 0,412 menunjukkan bahwa 41,2\% variasi variabel kinerja karyawan dapat dijelaskan oleh variabel employee engagement, sedangkan 58,8\% dijelaskan oleh variabel atau faktor lain.

Langkah 4, hasil analisis regresi untuk menguji hipotesis 4 menunjukkan bahwa setelah mengontrol variabel employee engagement, hubungan kepemimpinan transformasional pada kinerja karyawan tetap signifikan tetapi nilai koefisien berkurang $(\beta=0,416 ; \mathrm{t}=4,820 ; \mathrm{p}<0,05)$. Ini berarti employee engagement memediasi sebagian hubungan antara kepemimpinan transformasional dan kinerja karyawan. Koefisien determinasi $\left(\mathrm{R}^{2}\right)$ sebesar 0,517 menunjukkan bahwa $51,7 \%$ variasi variabel kinerja karyawan dapat dijelaskan oleh kepemimpinan transformasional dan employee engagement, sedangkan 48,3\% dijelaskan oleh variabel atau faktor lain.

Apabila digambarkan dalam bentuk model mediasi kepemimpinan transformasional $(\mathrm{X})$ pada kinerja karyawan $(\mathrm{Y})$ melalui mediator employee engagement (M) adalah sebagai berikut: 
Gambar 1 Hasil Regresi dengan Bentuk Mediasi

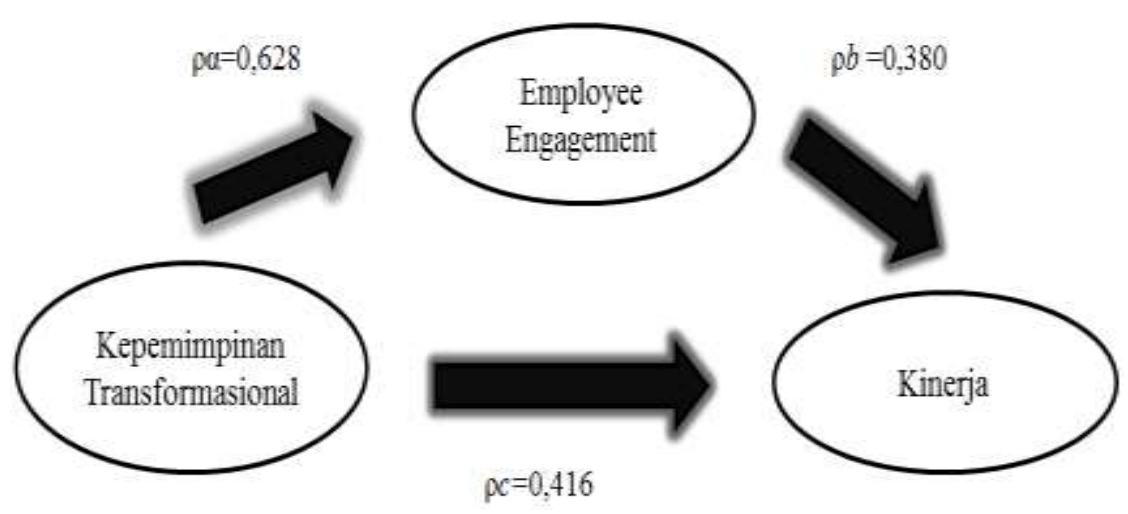

Sedangkan pengaruh tidak langsung antara kepemimpinan transformasional melalui employee engagement adalah $\rho \alpha \mathrm{X} \rho b=0,628 \times 0,380=0,239$ atau 23,9\%. Besaran pengaruh antara kepemimpinan transformasional pada kinerja karyawan menurun dari $41,6 \%$ menjadi $23,9 \%$ setelah melibatkan employee engagement sebagai pemediasi, maka dapat disimpulkan bahwa kepemimpinan transformasional dapat berpengaruh secara langsung maupun secara tidak langsung melalui employee engagement pada kinerja karyawan. Dengan demikian employee engagement dapat berperan sebagai mediasi secara parsial. Baron dan Kenny (1986) menyatakan bahwa secara prinsip berkurangnya tingkat signifikan pada path c menunjukkan kuatnya peran variabel mediator.

\section{Pembahasan hasil}

Hipotesis 1: Kepemimpinan transformasional Berpengaruh Positif Pada Kinerja Karyawan. Berdasarkan hasil uji hipotesis pertama menunjukkan bahwa kepemimpinan transformasional berpengaruh positif dan signifikan pada kinerja karyawan. Artinya ketika kepemimpinan transformasional mengalami peningkatan maka kinerja karyawan juga mengalami peningkatan.

Hasil penelitian ini selaras dengan hasil penelitian sebelumnya oleh Grant (2012) yang menyatakan bahwa pengaruh kepemimpinan transformasional pada kinerja karyawan memberikanj hasil yang positif dan signifikan. Kepemimpinan transformasional dapat meningkatkan kinerja karyawan dengan memotivasi mereka untuk lebih memperhatikan kepentingan bersama. Dengan kepemimpinan transformasional, karyawan akan lebih termotivasi ketika mereka memahami bahwa visi perusahaan juga bermanfaat bagi orang lain, seperti nasabah dan partner perusahaan.

Pembuktian melalui hasil uji hipotesis pertama menunjukkan bahwa karyawan dapat merasakan peran pemimpin yang berkarakter transformasional di Bank Perkreditan Rakyat Syari'ah Yogyakarta. Kepemimpinan transformasional dapat dilihat dari bagaimana pemimpin menjelaskan dan mengutarakan tujuan, serta membangun keyakinan terhadap visi, misi perusahaan secara jelas. Hal ini bertujuan agar karyawan mengetahui target perusahaan saat ini melalui programprogram kerja yang dapat memajukan perusahaan sehingga tujuan perusahaan tercapai. 
Dengan perilaku kepemimpinan yang berkarakter transformasional dalam Bank Perkreditan Rakyat Syari'ah Yogyakarta dapat menjadi suatu faktor yang dapat meningkatkan kinerja karyawan yang ditandai dengan meningkatnya aspek kinerja karyawan yang meliputi job, career, innovator, team dan organization (Welbourne et al., 1998).

Hipotesis 2: Kepemimpinan transformasional Berpengaruh Positif Pada Employee Engagement

Dari hasil analisis uji regresi diketahui bahwa hipotesis kedua terbukti, yaitu bahwa variabel kepemimpinan transformasional berpengaruh positif dan signifikan pada variabel employee engagement. Hasil penelitian tersebut sejalan dengan penelitian terdahulu yang dilakukan oleh Sharma dan Krishnan (2012) yang dengan konsisten menemukan bahwa kepemimpinan transformasional berhubungan positif dan signifikan pada employee engagement. Penelitian tentang kepemimpinan transformasional memang menarik untuk diteliti, terutama dalam kaitannya dengan usaha peningkatan employee engagement para bawahan. Peran seorang pemimpin sangat menentukan bagi pertumbuhan dan kelangsungan hidup suatu organisasi, termasuk di Bank Perkreditan Rakyat Syari'ahYogyakarta.

Kepemimpinan transformasional merupakan tipe kepemimpinan yang mengarah pada perubahan, memotivasi pengikut dalam proses pencapaian tugas melalui membangun visi bersama, menanamkan cita-cita dan nilai-nilai moral pada bawahannya, mengarah pada perubahan budaya organisasi, dan memotivasi bawahan untuk memperhatikan kepentingan kelompok. Pemimpin transformasional mampu mengidentifikasi masalah, menjabarkan dan kemudian menanganinya dengan penuh kehati-hatian. Hal tersebut mendorong peningkatan employee engagement dalam Bank Perkreditan Rakyat Syari'ah Yogyakarta. Sebagaimana diungkapkan juga oleh Papalexandris dan Galanaki (2009) bahwa gaya kepemimpinan transformasional diyakini mampu membangun employee engagement sehingga dapat membuat karyawan terikat secara emosional dengan pekerjaan dan lingkungannya.

Hipotesis 3: Employee Engagement Berpengaruh Positif pada Kinerja Karyawan

Berdasarkan hasil regresi yang dilakukan, dapat diketahui bahwa employee engagement berpengaruh positif pada kinerja karyawan yang berarti hipotesis ketiga terbukti. Hasil pengujian hipotesis ketiga ini sejalan dengan hasil penelitian yang telah dilakukan sebelumnya oleh Harter et al. (2002), yang menunjukkan bahwa adanya hubungan positif antara employee Engagement dan kinerja karyawan. Fisik dan emosional yang digunakan seorang karyawan dalam menjalankan pekerjaan akan berpengaruh terhadap tingkat keberhasilan seorang individu di dalam melaksanakan tanggung jawab pekerjaannya.

Semakin tinggi employee engagement semakin baik pula kinerja seseorang. Meningkatnya kinerja karyawan ditandai dengan meningkatnya jumlah output kerja, kualitas output kerja, akurasi kerja, serta peran karyawan untuk rekan kerjanya dalam menyelesaikan pekerjaan. Selain itu karyawan akan lebih berusaha untuk meningkatkan karirnya serta menjadi lebih kreatif. Karyawan juga melakukan hal-hal untuk membantu orang lain walaupun bukan bagian dari pekerjaannya, bekerja untuk kebaikan perusahaan, melakukan hal-hal untuk 
mempromosikan perusahaan, dan membantu perusahaan sehingga perusahaan menjadi lebih baik.

Hipotesis 4: Kepemimpinan transformasional berpengaruh positif pada kinerja dengan employee engagement sebagai variabel pemediasi.

Berdasarkan hasil pengujian hipotesis keempat dalam persamaan regresi yang dilakukan, semua persyaratan untuk membuktikan bahwa employee engagement memediasi secara parsial dalam hubungan kepemimpinan transformasional dan kinerja karyawan terpenuhi. Hasil pengujian regresi ini sesuai dengan temuan Pourbarkhordari et al. (2015) dimana transformational leadership berpengaruh positif pada kinerja karyawan dengan employee engagement sebagai variabel pemediasi sebagian (partially-mediated). Pemimpin yang mampu meningkatkan kinerja karyawan adalah pemimpin yang mampu meningkatkan antusias karyawan terhadap pekerjaan mereka. Hasil penelitian ini juga konsisten dengan hasil penelitian yang dilakukan oleh Sandell (2012), yang telah membuktikan bahwa employee engagement memediasi sebagian (partiallymediated) hubungan antara kepemimpinan transformasional dan kinerja karyawan. Karyawan yang memiliki employee engagement tinggi terhadap pekerjaannya ditandai dengan kepedulian yang besar terhadap tugasnya, adanya perasaan terikat secara psikologis terhadap tugas yang karyawan lakukan, dan keyakinan kuat kepada kemampuannya dalam menyelesaikan tugas.

\section{Simpulan}

Dari hasil penelitian diperoleh kesimpulan bahwa:

Hasil penelitian ini menjelaskan tentang pengaruh gaya kepemimpinan transformasional pada kinerja karyawan dengan employee engagement sebagai pemediasi. Responden adalah karyawan kantor Bank Perkreditan Rakyat Syari'ahYogyakarta. Dari hasil penelitian ini dapat disimpulkan bahwa:

Kepemimpinan transformasional berpengaruh positif dan signifikan pada kinerja karyawan. Hal ini berarti semakin tinggi kepemimpinan transformasional maka semakin tinggi pula kinerja karyawan.

Kepemimpinan transformasional berpengaruh positif dan signifikan pada employee engagement. Hal ini berarti semakin tinggi kepemimpinan transformasional maka semakin tinggi pula employee engagement.

Employee engagement berpengaruh positif dan signifikan pada kinerja karyawan. Hal ini berarti semakin tinggi employee engagement maka semakin tinggi pula kinerja karyawan.

Employee engagement berperan sebagai mediator dalam hubungan antara gaya kepemimpinan transformasional dan kinerja karyawan. Mediasi yang terjadi pada hubungan kepemimpinan transformasional dengan kinerja karyawan adalah mediasi parsial. Dengan demikian, kepemimpinan transformasional tetap mempengaruhi secara langsung kinerja karyawan walaupun pengaruhnya menurun. 


\section{DAFTAR PUSTAKA}

Aldoory, L. and Toth, E. (2004). Leadership And Gender In Public Relations: Perceived Effectiveness Of Transformational And Transactional Leadership Styles. Journal of Public Relations Research, 16, 157-183.

Avolio, B. J., Bass, B. M., and Jung, D. I. (1999). Re-examining The Components of Transformational and Transactional Leadership Using The Multifactor Leadership Questionnaire. Journal of Occupational and Organizational Psychology, 72, 441-462.

Bakker, A. and Schaufeli, W. (2003), "Work Engagement Scale," Journal of Occupational Health Psychology Unit Utrecht University, I, November, pp. 1-58.

Baron, R.M. and Kenny, D.A. (1986). The Moderator-Mediator Variable Distinction In Social Psychological Research: Conceptual, Strategic, And Statistical Considerations. Journal of Personality and Social Psychology, 51(6), 1173-1182.

Bass, B. M. (1985), Leadership and Performance Beyond Expectations. New York: The Free Press.

Bass, B. M. and Riggio, E. R. (2006), Transformational Leadership, $2^{\text {nd }}$ ed. New Jersey: Lawrence Erlbaum Asociates, Inc.

Blau, G. J. and Boal, K. B. (1987). Conceptualizing How Job Involvement and Organizational Commitment Affect Turnover and Absenteeism, Academy of Managernen Review, 12, 288-300.

Brown, E. A. (2008), Dimensions Of Transformational Leadership And Relationship with Employee Performance in Hotel Front Desk Staff, Master Thesis of Department of Food Service and Lodging Management Iowa State University.

Cartwright, S. and Holmes, N. (2006). The Meaning of Work: The Challenge of Regaining Employee Engagement and Reducing Cynicism. Human Resource Management Review, 16, 199-208.

Dale Carnegie and Associates, Inc. (2012), What Drives Employee Engagement and Why It Matters. Whitepaper. Dari http://www.dalecarnegie.com/assets/1/7/driveengagement_101612_wp.p df. Diakses Maret 6, 2016.

Fernandes, C. and Awamleh, R. (2004). The Impact Of Transformational And Transactional Leadership Styles On Employee's Satisfaction And Performance: An Empirical Test In A Multicultural Environment. International Business and Economics Research, 3(8), 65-76. 
Grant, A. M. (2012). Leading with Meaning: Beneficiary Contact, Prosocial Impact, And The Performance Effects of Transformational Leadership. Academy of Management Journal, 55( 2), 458-476.

Hameed, A. and Waheed, A. (2010). Employee Development and Its Affect on Employee Performance A Conceptual Framework. International Journal of Business and Social Science, 2(13), 224-229.

Harter, J. K., Schmidt, F.L., and Hayes, T.L. (2002). Business-Unit-Level Relationship Between Employee Satisfaction, Employee Engagement, and Business Outcomes: A Meta-Analysis. Journal of Applied Psychology, 87, 268-279.

Iqbal, A., Ijaz, M., Latif, F., and Mushtaq, H. (2015). Factors Affecting The Employee's Performance: A Case Study Of Banking Sector In Pakistan. European Journal of Business and Social Sciences, 4(8), 309 - 318.

James, A. O. and Ogbonna, I. G. (2013). Transformational vs. Transactional Leadership Theories: Evidence in Literature. International Review of Management and Business Research, 2(2), 355-361.

Jankingthong, K. and Rurkkhum, S. (2012). Factors Affecting Job Performance: A Review of Literature. Silpakorn University Journal of Social Sciences, Humanities, and Arts, 12(2), 115-127.

Jin, Y. (2010). Emotional Leadership As A Key Dimension Of Public Relations Leadership: National Survey Of Public Relations Leaders. Journal of Public Relations Research, 22(2), 159-181.

Jogiyanto, H.M. (2010), Metodologi Penelitian Bisnis: Salah Kaprah dan Pengalaman-Pengalaman, Yogyakarta: BPFE.

Macey, W. H. and Schneider, B. (2008). The Meaning of Employee Engagement. Industrial and Organizational Psychology: Perspectives on Science and Practice, 1, 3-30.

Markos, S. and Sridevi, M. S. (2010). Employee Engagement: The Key to Improving Performance. International Journal of Business and Management, 5(12), 89-96.

Papalexandris, N. and Galanaki, E. (2009). Leadership's Impact on Employee Engagement Differences among Entrepreneurs and Professional CEOs. Leadership and Organization Development Journal, 30(4), 365-385.

Pereira, C. M. and Gomes, J. F. (2012). The Strength of Human Resource Practices and Transformational Leadership: Impact on Organisational Performance. The International Journal of Human Resource Management, 23, 4301-4318. 
Pourbarkhordari, A., Zhou, E. H., and Pourkarimi, J. (2016). How Individualfocused Transformational Leadership Enhances Its Influence on Job Performance through Employee Work Engagement. International Journal of Business and Management, 11(2), 249-261.

Saetang, J., Sulumnad, K., Thampitak, P., and Sungkaew T. (2010). Factors Affecting Perceived Job Performance among Staff: A Case Study of Ban Karuna Juvenile Vocational Training Centre for Boys. Behavioral Science Research Institute, 5(1), 33-45.

Sandell, K. J. (2012), Transformational Leadership, Engagement, and Performance: A New Perspective, Master Thesis of Department of Psychology Colorado State University.

Schaufeli, W. and Bakker, A. (2003), Work Engagement Scale, Occupational Health Psychology Unit Utrecht University, dari http://www.beanmanaged.com/doc/pdf/arnoldbakker/articles/articles_arn old_bakker_87.pdf. Diakses Mei 31, 2016

Schaufeli, W. B., Martinez, I., Marques P. A., Salanova, M., and Bakker, A. B. (2002). Burnout and engagement in university students: A Cross National Study. Journal of Cross Cultural Psychology, 33, 464-481.

Sekaran, U. and Bougie, R. J. (2013), Research Methods for Business: A SkillBuilding Approach. Chichester: John Wiley and Sons Ltd.

Sharma, D. and Krishnan, V. R. (2012). The Impact of Pay Satisfaction and Transformational Leadership on Employee Engagement. Proceedings of the 5th International Conference of Management and Behavioural Sciences, Haridwar, India, June, pp. 1-12.

Sultana, A., Irum, S., Ahmed, K., and Mahmood, N. (2012). Impact of Training on Employee Performance: A Study of Telecommunication Sector in Pakistan. Interdisciplinary Journal of Contemporary Research in Business, 4(6), 646-661.

Uzonna, U. R. (2013). Impact Of Motivation On Employee's Performance: A Case Study Of Credit West Bank Cyprus. Journal of Economics and International Finance, 5(5), 199-211.

Wang, G., Oh, I., Courtright, S. H., and Colbert, A. E. (2011). Transformational leadership and performance across criteria and levels: A meta-analytic review of 25 years of research. Group and Organization Management, $36,223-270$.

Welbourne, T. M., Johnson, D. E., and Erez, A. (1998). The Role-Based Performance Scale: Validity Analysis of A Theory-Based Measure. Academy of Management Journal, 41(5), 540-555. 
Wong, W. P. and Wong, K. Y. (2007).Supply Chain Performance Measurement System Using DEA Modeling. Industrial Management and Data Systems, 107(3), 361-81. 